\title{
Rhabdomyolysis Leading to Acute Kidney Injury
}

\author{
Sajad Ahmad, Muhammad Anees, Irfan Elahi and Fazal-e-Mateen \\ Department of Nephrology, Mayo Hospital, King Edward Medical University, Lahore, Pakistan
}

\begin{abstract}
Rhabdomyolysis constitutes an uncommon cause of acute kidney injury (AKI). A large variety of causes with different pathogenic mechanisms may involve skeletal muscles resulting in rhabdomyolysis with or without acute kidney injury. Crush syndrome and unaccustomed physical exertion are the most common causes of rhabdomyolysis. This study reports local cases of AKI secondary to rhabdomyolysis that presented to a tertiary care centre over a period of four years. Most of them were males and belonged to younger age group. Muscle enzyme creatine phosphokinase level was raised in all patients, while myoglobinuria was detected only in one patient. Most of the patients (10/16) were managed conservatively with fluid replacement; and some of them (6/16) needed dialysis. AKI was resolved in all the patients after a variable period of time.
\end{abstract}

Key Words: Rhabdomyolysis, Acute kidney injury, Myoglobinuria, Creatine phosphokinase, Trauma.

How to cite this article: Ahmad S, Anees M, Elahi I, FEM. Rhabdomyolysis Leading to Acute Kidney Injury. J Coll Physicians Surg Pak 2021; 31(02):235-237.

Rhabdomyolysis is defined as injury to skeletal muscle cells of such severity that their contents (electrolytes, myoglobin, enzymes: creatine phosphokinase [CPK], aldolase, lactate dehydrogenase $[\mathrm{LDH}]$ ), are released into the circulation. ${ }^{1,2}$ Clinical presentation ranges from an asymptomatic elevation in the CPK level to a life-threatening condition associated with extreme elevations in CPK, electrolyte imbalances and acute kidney injury (AKI). ${ }^{3}$ According to previously published studies, about $10-50 \%$ of patients with rhabdomyolysis develop AKI. ${ }^{4}$ The first description of the consequences of traumatic muscle injury on kidney function was attributed to Bywaters and Beall, who reported four cases of crush injury of the limbs at the time of the German blitz of London during World Warll. ${ }^{5}$

The pathogenesis of AKI in rhabdomyolysis is multifactorial. The proposed mechanisms are hypovolemia leading to renal ischemia and toxicity of myoglobin: direct tubular toxicity, vasoconstriction and intra-tubular cast formation. ${ }^{1}$

The management of rhabdomyolysis includes the measures to prevent AKI, treatment of established AKI, and of related complications. Fluid resuscitation and bicarbonate replacement has got key role in prevention of rhabdomyolysis induced AKI.

Correspondence to: Dr. Sajad Ahmad, Department of Nephrology, Mayo Hospital, King Edward Medical University, Lahore, Pakistan

E-mail:dr.sajjadahmad@gmail.com

Received: November 22, 2019; Revised: September 16, 2020; Accepted: September 26, 2020

DOI: https://doi.org/10.29271/jcpsp.2021.02.235
Volume status of the patient should be carefully assessed. Fluids are titrated to maintain urine output of 200 to $300 \mathrm{~mL} / \mathrm{hr}$. A forced alkaline diuresis, in which the urine $\mathrm{pH}$ is raised to above 6.5, may diminish the renal toxicity of heme. ${ }^{6}$

In this study, patients admitted at Nephrology Department of Mayo Hospital, Lahore from August 2015 to September 2019 with the diagnosis of rhabdomyolysis and acute kidney injury were reviewed. Information was collected from patient histories, physical examinations, nursing records, and laboratory reports. Data included patients' age, gender, profession, comorbidities, risk factors for rhabdomyolysis (drug abuse, unusual exercise, running, fall, trauma, compression etc), presenting symptoms, important physical signs, diagnosis, hospital course and outcome. Laboratory data of blood urea nitrogen (BUN), serum creatinine $(\mathrm{S} / \mathrm{Cr})$, serum potassium, calcium, phosphorus, creatine phosphokinase (CPK), uric acid, lactate dehydrogenase (LDH), urine complete, especially for hematuria, proteinuria and myoglobinuria were extracted from patients' records.

The diagnosis of rhabdomyolysis was supported by the typical history of precipitating events, symptoms of muscle weakness and generalised myalgias, laboratory data of CPK level $>1000$ $\mathrm{U} / \mathrm{L}$ (normal range: 0 to 185 ) and dipstick positive hematuria without significant RBC's on urine microscopy. The diagnosis of AKI was made on the basis of an increase in serum creatinine of $0.3 \mathrm{mg} / \mathrm{dl}$ or more within 48 hours or reduction in urine output below $0.5 \mathrm{ml} / \mathrm{kg} / \mathrm{h}$ for six hours in the absence of pre-existing renal disease, using kidney disease improving global outcomes (KDIGO), composite staging of AKI criteria.

Demographic data and disease course are presented in the Tablel. 


\begin{tabular}{|c|c|c|c|c|c|}
\hline $\begin{array}{l}\text { Patient } \\
\text { number }\end{array}$ & $\begin{array}{l}\text { Age (years) / } \\
\text { gender }\end{array}$ & $\begin{array}{l}\text { Risk factors / } \\
\text { co-morbidities }\end{array}$ & Symptoms & Need for dialysis & $\begin{array}{l}\text { AKI resolved in } \\
\text { (days) }\end{array}$ \\
\hline 1 & $22 / \mathrm{M}$ & $\begin{array}{l}\text { Heavy exerti gon at } \\
\text { fitness club }\end{array}$ & Flank pain / Oliguria / N\&V /SOB & $\begin{array}{l}\text { Conservative } \\
\text { management }\end{array}$ & 10 \\
\hline 2 & $27 / F$ & $\begin{array}{l}\text { Physical assault by } \\
\text { dacoits }\end{array}$ & $\begin{array}{l}\text { Muscle pains \& cramps / } \\
\text { Oliguria / N\&V }\end{array}$ & $\begin{array}{l}\text { Acute peritoneal } \\
\text { dialysis }\end{array}$ & 22 \\
\hline 3 & $42 / \mathrm{M}$ & Drug abuse (heroin) & Oliguria / N\&V & Hemodialysis & 18 \\
\hline 4 & $20 / M$ & Unusual running & Flank pain / Oliguria / N\&V & $\begin{array}{l}\text { Conservative } \\
\text { management }\end{array}$ & 12 \\
\hline 5 & $45 / F$ & $\begin{array}{l}\text { Heavy exertion during } \\
\text { Hajj / hypertension }\end{array}$ & Oliguria / N\&V / SOB & Hemodialysis & 28 \\
\hline 6 & $26 / M$ & Heavy exertion (sit ups) & $\begin{array}{l}\text { Muscle pains \& cramps / N\&V / } \\
\text { SOB }\end{array}$ & $\begin{array}{l}\text { Acute peritoneal } \\
\text { dialysis }\end{array}$ & 08 \\
\hline 7 & $15 / M$ & $\begin{array}{l}\text { Road traffic accident, } \\
\text { fracture right femur, } \\
\text { degloving injury }\end{array}$ & Oliguria/SOB & $\begin{array}{l}\text { Conservative } \\
\text { management }\end{array}$ & 20 \\
\hline 8 & $17 / \mathrm{F}$ & $\begin{array}{l}\text { Generalized weakness } \\
\text { and burning of feet }\end{array}$ & $\begin{array}{l}\text { Muscle pains \& cramps / } \\
\text { Oliguria / N\&V }\end{array}$ & $\begin{array}{l}\text { Conservative } \\
\text { management }\end{array}$ & 14 \\
\hline 9 & $35 / M$ & $\begin{array}{l}\text { Right leg swelling and } \\
\text { fever / diabetes mellitus }\end{array}$ & Muscle pains \& cramps / SOB & $\begin{array}{l}\text { Conservative } \\
\text { management }\end{array}$ & 17 \\
\hline 10 & $38 / \mathrm{M}$ & $\begin{array}{l}\text { Fall of heavy machinary, } \\
\text { crush injury of right arm } \\
\text { S/P axillary artery embo- } \\
\text { lectomy / Hepatitis C }\end{array}$ & Oliguria & $\begin{array}{l}\text { Conservative } \\
\text { management }\end{array}$ & 21 \\
\hline 11 & $70 / F$ & $\begin{array}{l}\text { Fall at home / Ischemic } \\
\text { heart disease and } \\
\text { hypertension }\end{array}$ & Oliguria / N\&V & $\begin{array}{l}\text { Conservative } \\
\text { management }\end{array}$ & 18 \\
\hline 12 & $36 / M$ & Heavy exertion & Muscle pains \& cramps / N\&V & $\begin{array}{l}\text { Conservative } \\
\text { management }\end{array}$ & 11 \\
\hline 13 & $36 / M$ & $\begin{array}{l}\text { Electric shock / } \\
\text { Hypertension }\end{array}$ & Flank pain / N\&V & $\begin{array}{l}\text { Conservative } \\
\text { management }\end{array}$ & 35 \\
\hline 14 & 23/M & $\begin{array}{l}\text { Heavy exertion / } \\
\text { hypertension }\end{array}$ & Oliguria / N\&V & Hemodialysis & 21 \\
\hline 15 & $31 / \mathrm{M}$ & Unusual exertion & $\begin{array}{l}\text { Oliguria/N\&V/Flank pain/Muscle } \\
\text { cramps/SOB }\end{array}$ & $\begin{array}{l}\text { Conservative } \\
\text { management }\end{array}$ & 18 \\
\hline 16 & $23 / M$ & Unusual exertion & $\begin{array}{l}\text { Oliguria/N\&V/Flank pain/Muscle } \\
\text { cramps }\end{array}$ & Hemodialysis & 22 \\
\hline
\end{tabular}

Thirteen patients $(81.3 \%)$ were males and three (18.8\%) were females. Mean age of the patients was $31.62 \pm 13.58$ years with the range of 15 to 70 years. Three patients were previously hypertensive, one was anti HCV + ve, one was diabetic and one patient had ischemic heart disease; but majority 10/16 (62.5\%) had no comorbidities.

Unusual exertion and trauma ( $50 \%$ and $25 \%$, respectively) were the major precipitating events ( $75 \%$ collectively). Major symptoms at presentation were nausea and vomiting $(81.3 \%)$, and oliguria (75\%). On physical examination, 10 patients were hypertensive, five were normotensive, and one had low blood pressure of 90/50 millimeter of mercury $(\mathrm{mmHg})$. Mean systolic blood pressure was $136 \pm 23 \mathrm{mmHg}$, while mean diastolic blood pressure was $80 \pm 24 \mathrm{mmHg}$. Most of the patients were in fluid overload state 11/16 $(68.8 \%)$, four were euvolemic, and one patient was dehydrated at presentation.

At presentation, all the patients had increased levels of the muscle enzyme CPK: mean value was $34992 \pm 53183 \mathrm{u} / \mathrm{L}$ that ranged from 1179 to 197800 . In this study, myoglobinuria was checked in nine patients and was positive only in one patient 01/09 (11.1\%). LDH levels were increased in 11 patients (mean value of $2003 \pm 3169 \mathrm{u} / \mathrm{L}$ with minimum 445 and maximum 11330). All the patients had AKI at the time of presentation with $14 / 16(87.5 \%)$ had KDIGO stage 3 and $2 / 16(12.5 \%)$ had KDIGO stage 2 AKI. Mean blood urea nitrogen (BUN) was $97.5 \pm 52.5 \mathrm{mg} / \mathrm{dL}$ (ranged from 36 to $225 \mathrm{mg} / \mathrm{dL}$ ), and mean serum creatinine was $9.5 \pm 5 \mathrm{mg} / \mathrm{dL}$ (ranged from 2.5 to $19.4 \mathrm{mg} / \mathrm{dL}$ ). Twelve patients had hyperuricemia with mean value $11.8 \pm 4.1$. Serum potassium was in the range of 3.7 to $6.5 \mathrm{mg} / \mathrm{dL}$ with mean value of $4.8 \pm$ $0.9 \mathrm{mg} / \mathrm{dL}$. Mean serum calcium was $8.1 \pm 1 \mathrm{mg} / \mathrm{dL}$ (ranged from 6 to $9.9 \mathrm{mg} / \mathrm{dL}$ ). Eleven patients had hyperphosphatemia, mean value $5.6 \pm 1.7$, and were normal in rest of them. During course of the disease, six patients required dialysis (two patients had acute peritoneal dialysis and four patients had hemodialysis sessions); while, nine patients were managed conservatively. All patients were given isotonic bicarbonate ( $5 \%$ dextrose water with bicarbonate), according to their volume status judiciously. AKI resolved in all the patients over variable period of time, mean duration was $18.4 \pm 6.8$ days that ranged between 8 to 35 days.

Majority of the patients had KDIGO stage III AKI at presentation, which could be attributed to the severity of inciting events as well as their late referral to nephrology. All 
patients had increased levels of the muscle enzyme CPK in this study, which is also feature of previously documented literature. $^{2}$ In a large case series by Naqvi et al., ${ }^{4}$ patients had no comorbid; but in our study, 37.5\% patients have different comorbids; but as their AKI had completely resolved, it can be said that they did not have pre-existing chronic kidney disease. Although our study is small-sized and shows single centre experience, but it can be concluded that special attention should be given to patients presenting with typical history and risk factors that can predispose to muscle damage. These patients should be evaluated with basic laboratory tests (BUN, S/Cr, CPK, LDH, serum uric acid) to rule out rhabdomyolysis and $A K I$. It is also a fair bet to prevent and treat rhabdomyolysis-induced AKI with adequate and judicious fluid resuscitation at an earlier stage.

\section{CONFLICT OF INTEREST:}

All authors declared no conflict of interest.

\section{AUTHORS' CONTRIBUTION:}

SA: Concept, data acquisition, analysis.
MA: Concept, critical review, final approval.

IE: Critical review.

FM: Drafting of the work, and critical review.

\section{REFERENCES}

1. Malik GH. Rhabdomyolysis and myoglobin-induced acute renal failure. Saudi J Kidney Dis Transpl 1999; 9(4):273-84.

2. Nayak S, Jindal A. Myoglobinuria and Acute Kidney Injury. J Integr Nephrol Androl 2015; 2:50-4.

3. Huerta-Alard'in AL, Varon J, Marik PE. Bench-to-bedside review: Rhabdomyolysis - an overview for clinicians. Crit Care 2005; 9(2):158-69. doi: 10.1186/cc2978.

4. Naqvi R, Akhtar F, Ahmed E, Naqvi A. Rizvi A. Acute kidney injury with rhabdomyolysis: 25 Years' experience from a tertiary care center. Open J Nephrol 2015; 5:67-74.

5. Bywaters E, Beall D. Crush injuries with impairment of renal function. $\mathrm{Br}$ Med J 1941; 1:427-32. doi: 10.1136/bmj.1.4185.427.

6. FY Khan. Rhabdomyolysis: A review of the literature. Netherlands J Med 2009; 67(9):272-83. 